\title{
PENGEMBANGAN PERANGKAT PEMBELAJARAN FISIKA AKTIF TIPE LEARNING TOURNAMENT BERBASIS LOCAL WISDOM
}

\author{
Wahyu Trias Wulandari dan Mundilarto \\ FMIPA Universitas Negeri Yogyakarta \\ email: Wulandari34h@gmail.com
}

\begin{abstract}
Abstrak: Penelitian bertujuan untuk mendeskripsikan: (1) kelayakan perangkat pembelajaran fisika aktif tipe learning tournament berbasis local wisdom Kabupaten Purworejo untuk meningkatkan kemampuan pemahaman konsep dan nilai karakter; (2) peningkatan kemampuan pemahaman konsep siswa setelah menggunakan perangkat pembelajaran fisika aktif tipe learning tournament berbasis local wisdom; (3) peningkatan nilai karakter siswa setelah menggunakan perangkat pembelajaran fisika aktif tipe learning tournament berbasis local wisdom; (4) keefektifan perangkat pembelajaran fisika aktif tipe learning tournament berbasis local wisdom untuk meningkatkan kemampuan pemahaman konsep dan nilai karakter siswa. Teknik pengumpulan data dilakukan lewat observasi, tes, dan angket, sedang analisis dengan N-Gain dan manova. Penelitian pengembangan ini menggunakan model $4 D$, yaitu tahap define, design, develop, dan disseminate. Hasil penelitian menunjukkan bahwa perangkat pembelajaran yang dikembangkan dapat meningkatkan kemampuan pemahaman konsep dan nilai karakter dengan efektif. Hal ini ditunjukkan berdasarkan penilaian expert judgment serta $\mathrm{N}$-Gain yang mendukung serta adanya perbedaan peningkatan kemampuan pemahaman konsep dan nilai karakter yang signifikan antara kelas eksperimen dan kelas kontrol.
\end{abstract}

Kata Kunci: perangkat pembelajaran, pembelajaran fisika, active learning, learning tournament, local wisdom, kemampuan pemahaman konsep, nilai karakter

\section{DEVELOPING PHYSICS ACTIVE LEARNING KITS FOR LOCAL WISDOM-BASED LEARNING TOURNAMENT}

\begin{abstract}
The objectives of this research are (1) to delineate the feasibility of physics active learning kits of learning tournament based on Purworejo local wisdom to improve students' understanding on the concept and values of characters; (2) to describe the improvement of students' conceptual understanding after using the physics active learning kits; (3) to describe the improvement of students' character values after using the physics active learning kits;(4) to describe the effectiveness of the kits in improving students' understanding on the concept and values of characters. This developmental study used 4D model which involves four stages, i.e. define, design, develop, and disseminate. The results of this research show that the physics active learning kits effectively improve students' understanding on the concept and values of characters. This fact is shown by supporting expert assessment and N-Gain and through the difference of students' understanding on the concept and values of character in the experiment class and that in control class.
\end{abstract}

Keywords: Learning instrument, physics learning, active learning, learning tournament, local wisdom, conceptual understanding, character values

\section{PENDAHULUAN}

Abad XXI menuntut respon terhadap berbagai perkembangan dalam segala aspek secara kritis.Kemajuan teknologi ilmu pengetahuan, memicu perkembangan terhadap aspek lingkungan hidup, kesehatan, ekonomi, dan aspek lainnya.Perkembangan IPTEK menjadi suatu kewajiban untuk merespon bagi setiap orang karena hal tersebut menuntut setiap individu untuk lebih menyesuaikan diri menghadapi perubahan.

Fisika merupakan salah satu ilmu yang mendasari penemuan dan perkembangan pengetahuan dan teknologi modern.Pesatnya perkembangan sains dan teknologi dalam kehidupan masyarakat pada abad ini menuntut manusia untuk semakin berinovasi dalam segala aspek 
kehidupan.Besarnya peran fisika dalam perkembangan teknologi menuntut pendidikan fisika untuk mengacu pada hasil belajar yang dilandasi dengan pemahaman konsep.

Pemahaman konsep merupakan pijakan pertama dalam mengembangkan konsep dan menghubungkan dengan pemahaman ilmu yang telah diperoleh sebelumnya. Apabila persepsi terhadap gejala alam tidak utuh, maka pemahaman konsep tidak dapat tercapai dengan baik. Oleh karena itu, siswa mengalami kesalahan dalam menemukan solusi untuk mengatasi masalah yang ada di sekitarnya. Upaya mempersiapkan siswa menghadapi arus globalisasi yang berbasis IPTEK seperti yang terjadi sekarang ini diperlukan penanaman karakter yang kuat.

Upaya dalam meningkatkan aspek pemahaman konsep dapat diraih dengan menanamkan keyakinan dalam diri siswa. Sahin (2010:534) membuktikan bahwa keyakinan siswa yang berkaitan dengan konseptual dapat membantu siswa meraih kemampuan pemahaman konsep. Keyakinan siswa dapat diraih apabila siswa dilibatkan dalam kegiatan menemukan konsep secara aktif dalam pembelajaran. Diduga, apabila siswa menemukan sendiri bukti dari konsep tersebut, keyakinan siswa akan tumbuh seiring dengan berkembangnya konsep yang diperolehnya.

Selain itu, ada kecenderungan bahwa pembelajaran aktif yang interaktif dalam pembelajaran fisika dapat meningkatkan keefektifan dalam meningkatkan pemahaman konsep siswa.Hal ini didasarkan pada pertimbangan bahwa pemahaman konsep siswa menjadi kunci dalam mengembangkan kemampuan pemecahan masalah (Antwi, Hanson, Sam, Savlsbergh, \& Eijkelhof, 2011:90). Pemahaman konsep dapat diperoleh melalui pembelajaran yang aktif dan mengikutsertakan siswa dalam menemukan sendiri konsep fisika. Oleh karena itu, pemahaman konsep merupakan kompetensi akademik yang harus dimiliki siswa agar siswa dapat mengembangkan kemampuan lainnya.

Selain menyiapkan siswa untuk memiliki kompetensi akademik yang baik, pendidikan pada dasarnya bertujuan untuk membentuk karakter siswa. Tujuan yang diharapkan dalam pendidikan tertuang dalam undang-undang nomor 20 tahun 2003 tentang sistem pendidikan nasional dalam pasal 3. Undang-undang tersebut menegaskan bahwa pendidikan nasional bertujuan untuk berkembangnya potensi peserta didik yang berbasis karakter.
Disusunnya aturan mengenai pelaksanaan pendidikan karakter secara formal mengindikasikan bahwa kebutuhan akan pembentukan karakter merupakan hal yang vital. Pala (2011:31) membuktikan bahwa pengembangan keterampilan sosial dan integrasi pendidikan karakter merupakan bagian penting dari keberhasilan akademis. Upaya pendidikan karakter efektif bila diterapkan secara ketat dengan dasar ilmiah. Sekolah sebaiknya fokus pada pembelajaran karakter dalam kurikulum regular.

Pendidikan karakter mengacu pada pembelajaran melalui fakta, konsep, teori, hukum, dan prinsip sehingga menghasilkan nilai dan moral. Pembelajaran nilai dan moral merupakan komponen yang tidak terpisahkan dari pendidikan kewarganegaraan. Siswa perlu dilatih untuk berperilaku konstruktif dalam sehari-hari dan bermasyarakat. Hal ini dikarenakan sudah maraknya krisis sosial yang menyimpang dari moral yang baik (Silay, 2014:9).

Aktualisasi program pendidikan karakter ke dalam pembelajaran diperlukan untuk mengatasi krisis karakter bangsa. Upaya pembentukan moral generasi muda harus dilakukan demi masa depan. Pembelajaran karakter berguna dalam perkembangan moral berdasarkan konsep etika yang baik (Gray, 2010:61). Oleh karena itu, pendidikan karakter penting untuk diterapkan dalam setiap pembelajaran di kelas, termasuk dalam pendidikan fisika.

Fisika mengacu pada fenomena sehari-hari, termasuk hal yang sudah menjadi budaya daerah bernilai luhur.Aspek budaya lokal dalam pembelajaran fisika dapat memberikan peluang siswa untuk mengembangkan pemahaman konsep. Hal ini karena analisis fisika dilakukan secara langsung dalam suatu objek nyata, bukan hanya abstraksi konsep semata. Apabila guru dapat menghadirkan local wisdom dimana siswa tinggal serta mengkajinya dari sudut pandang fisika, maka makna dari ilmu fisika dapat diterima siswa dan dipahami lebih baik.

Peran penting dari pengangkatan local wisdom memberikan efek jangka panjang yang besar. Hal ini dibuktikan oleh Widodo (2012:11) bahwa dengan mempelajari, memahami, mengadaptasi, menyesuaikan, menerjemahkan, dan merekonstruksi local wisdom untuk keperluan pembelajaran cendekiawan masa depan dapat memberikan kunci pemahaman umum dari nilai yang dikandung. Nilai yang dikandung berfungsi 
sebagai titik awal dalam mengubah paradigma terhadap suatu tindakan yang lebih masuk akal, sensitif, dan kontekstual. Oleh karena itu, selain materi fisika dapat disampaikan secara kontekstual dengan baik, pengintegrasian local wisdom dalam pembelajaran diduga mampu membentuk karakter siswa. Karakter ini bersumber dari local wisdom yang memiliki nilai luhur sehingga siswa dapat menghadapi perkembangan zaman namun tetap memiliki budi yang luhur.

Penelitian yang dilakukan oleh Ardan, Ardi, Yusminah, Suou, \& Dirawan (2015:58) membuktikan bahwa local wisdom suatu daerah dapat diterapkan dalam pembelajaran.Hal ini dapat menunjang program pelestarian local wisdom sehingga tidak tergeser oleh perkembangan zaman. Oleh karena itu, dengan mengintegrasikan local wisdom, maka pengetahuan dan nilai kebudayaan dapat disampaikan kepada siswa sebagai efek pengiring. Hasilnya, siswa tidak meninggalkan local wisdom yang dimiliki oleh daerahnya.

Keberhasilan dalam kegiatan pembelajaran dapat diukur melalui beberapa komponen. Weno (2010) menyebutkan beberapa komponen yang dapat digunakan untuk mengukur keberhasilan proses pembelajaran sains, yakni variabel kualitas proses belajar mengajar sains, sikap siswa terhadap sains, minat belajar siswa, dan kemampuan siswa memecahkan masalah sains dan variabel sarana prasarana dapat dikategorikan cukup. Usaha dalam mencapai keadaan tersebut juga dipengaruhi oleh model pembelajaran.Pemilihan model pembelajaran hendaknya memperhatikan karakteristik siswa serta kompetensi yang ingin dicapai. Morales \& Toledano (2013:79) mengungkapkan bahwa pembelajaran yang berlangsung aktif dan kolaboratif dapat menumbuhkan kreativitas yang lebih daripada menggunakan metode konvensional yang menempatkan siswa sebagai penerima informasi dari guru.Pembelajaran aktif cenderung memicu siswa untuk menjadi subjek pembelajaran yang aktif dan kolaboratif. Salah satu tipe pembelajaran aktif yang memenuhi hal tersebut adalah learning tournament.

Pembelajaran aktif tipe learning tournament memiliki potensi yang besar dalam pencapaian pembelajaran. Hal ini dikarenakan siswa dipacu agar secara aktif saling berkomunikasi secara kolaboratif dan terorganisir untuk berfikir bersama dalam menemukan solusi pemecahan permasalahan. Pernyataan ini didukung oleh pe- nelitian Ninck (2013:16-18) yang membuktikan bahwa beberapa keterampilan tindakan yang dilakukan siswa seperti komunikasi, kolaborasi, penemuan tim, belajar berdasarkan pertanyaan, sistem berfikir, pemecahan masalah, refleksi, dan pembelajaran terorganisasi memberikan benefit yang tinggi. Selain tujuan pembelajaran dapat tercapai dengan optimal, penerapan pembelajaran aktif tipe learning tournament berpotensi untuk menyiapkan siswa agar memiliki keterampilan yang diperlukan untuk hidup bermasyarakat.

Implementasi pembelajaran aktif tipe learning tournament berbasis local wisdom dapat memberikan ruang kepada siswa untuk aktif, kompetitif, dan kolaboratif dalam berdiskusi dengan melibatkan kemampuan berpikir serta menuangkan gagasan dengan dasar yang benar untuk memperoleh pemahaman konsep dengan mengkaji local wisdom yang ada di daerah tersebut. Pembelajaran aktif mempunyai prinsip bahwa cara belajar terbaik adalah dengan melakukannya, menggunakan semua indera, mengeksplorasi lingkungannya, belajar dari pengalaman langsung dan konkret, serta berbagai bentuk pengalaman lainnya. Hal ini dapat merangsang siswa untuk terus menggali kemampuan masing-masing individu untuk secara aktif belajar dalam kelompok.

Berdasarkan pertimbangan tersebut, perlu dikembangkan perangkat pembelajaran fisika dengan memanfaatkan model pembelajaran fisika aktif tipe learning tournament berbasis local wisdom Kabupaten Purworejo. Penerapan perangkat pembelajaran ini diharapkan dapat membantu siswa untuk meningkatkan pemahaman konsep serta mampu meningkatkan nilai-nilai karakter siswa siswa.

\section{METODE}

Penelitian ini mengembangkan perangkat pembelajaran fisika aktif tipe learning tournament berbasis local wisdom Kabupaten Purworejo. Model pengembangan yang digunakan dalam penelitian ini adalah model $4 \mathrm{D}$. Model $4 \mathrm{D}$ terdiri atas empat tahap, yaitu define, design, develop, dan disseminate (Thiagarajan, Semmel, \& Semmel, 1974:6-9). Tahap define terdiri atas kegiatan studi pendahuluan, analisis siswa, analisis tugas, analisis konsep, serta spesifikasi tujuan pembelajaran. Pada studi pendahuluan, dilakukan dua tahap yaitu studi pustaka dan studi lapangan.Hasil dari studi pendahuluan digunakan menjadi dasar pengembangan perangkat pembelajaran. 
Tahap design terdiri atas kegiatan merancang format perangkat pembelajaran serta merancang draf perangkat pembelajaran berdasarkan format yangtelah disusun. Draf yang telah disusun disebut Draf I. Draf I terdiri atas RPP, handout, dan LKS. Tahap develop terdiri atas validasi instrumen penilaian perangkat pembelajaran, penilaian perangkat pembelajaran, evaluasi dan revisi I, uji coba terbatas, evaluasi dan revisi II, uji coba lapangan, serta evaluasi dan penyempurnaan perangkat pembelajaran. Tahap terakhir adalah disseminate. Pada tahap ini, dilakukan penyebarluasan produk dalam jumlah terbatas pada sekolah di Kabupaten Purworejo.

Penelitian dilakukan di SMA Negeri 5 Purworejo dan SMA Negeri 1 Purworejo dengan subjek penelitian masing-masing berjumlah 32 orang dan 64 orang kelas X SMA. Siswa SMA Negeri 5 Purworejo dipakai sebagai subjek pada uji coba terbatas, sedangkan siswa SMA Negeri 1 Purworejo sebagai subjek pada uji coba lapangan. Pada uji coba lapangan, siswa dibagi menjadi dua kelas, yaitu kelas eksperimen dan kelas kontrol.

Teknik pengumpulan data yang digunakan dalam penelitian ini adalah observasi, tes, dan angket.Observasi dilakukan untuk mendapatkan data mengenai kondisi sekolah, siswa, lingkungan belajar siswa di sekolah, dan RPP. Angket digunakan untuk mengetahui peningkatan nilai karakter siswa setelah menggunakan perangkat pembelajaran fisika aktif tipe learning tournament berbasis local wisdom, danuntuk mengetahui respon siswa terhadap perangkat yang telah dikembangkan. Tes dilakukan untuk mengetahui peningkatan kemampuan pemahaman konsep yang dimiliki siswa. Teknik analisis data hasil validasi instrumen penilaian perangkat pembelajaran dilakukan dengan menghitung persentase validitas butir yang valid.Analisis data hasil penilaian perangkat pembelajaran dilakukan denganmenentukan skor rerata dari kriteria dalam setiap aspek. Setelah itu, menentukan kriteria penilaian skala lima yang diungkapkan oleh Sukardjo (2006:53).Adapun kriteria penilaian yang telah disesuaikan dengan penelitian ini ditampilkan pada Tabel 1 .
Tabel 1. Konversi Skor Aktual Menjadi Kategori Kualitatif untuk Interval 1 sampai 5

\begin{tabular}{ccc}
\hline No & Interval Skor & Kategori \\
\hline 1 & $4,2<\bar{X}$ & Sangat baik \\
2 & $3,4<\bar{X} \leq 4,2$ & Baik \\
3 & $2,6<\bar{X} \leq 3,4$ & Cukup \\
4 & $1,8<\bar{X} \leq 2,6$ & Kurang \\
5 & $\bar{X} \leq 1,8$ & Sangat kurang \\
\hline
\end{tabular}

Hasil skor peningkatan pemahaman konsep dan nilai karakter setelah dilakukan pembelajaran menggunakan perangkat yang dikembangkan dilakukan uji $N$-gain Hake (1993). Tetapi, sebelum dilakukan uji $N$-Gain, data karakter siswa diubah terlebih dahulu dari skala ordinal kedalam skala interval menggunakan method of successive interval (MSI) dengan bantuan program XLSTAT 97 yang ditambahkan pada microsoft excel.

Uji gain dengan rumus sebagai berikut.

Std gain $<g>=\frac{\bar{X}_{\text {postest }}-\bar{X}_{\text {pretest }}}{\bar{X}-\bar{X}_{\text {pretest }}}$

Nilai standar gain yang dihasilkan diintepretasikan sesuai Tabel 2.

Tabel 2. Kriteria Nilai Gain

\begin{tabular}{ll}
\hline \multicolumn{1}{c}{ Nilai $<\mathrm{g}>$} & Klasifikasi \\
\hline$<\mathrm{g}>\geq 0,7$ & Tinggi \\
$0,7><\mathrm{g}>\geq 0,3$ & Sedang \\
$<\mathrm{g}><0,3$ & Rendah \\
\hline
\end{tabular}

(sumber: Hake, 1993:1)

Analisis peningkatan persentase kriteria ketuntasan minimal (KKM) dilakukan dengan menentukan kenaikan persentase ketuntasan sebelum dan sesudah dilakukan pembelajaran. Persentase ketuntasan dapat diketahui dengan menggunakan persamaan berikut.

$P=\frac{\sum X}{n} \times 100 \%$

Selain itu, dilakukan pula uji validitas dan reliabilitas terhadap hasil penilaian perangkat pembelajaran.Uji validitas menggunakan Aiken's V yang dikembangkan oleh Aiken (1985:133). Kriteria yang digunakan dalam penentuan batas 
koefisien Aiken's V adalah $\geq 0,88$. Reliabilitas penilaian perangkat pembelajaran ditentukan dengan menggunakan persentase kesepakatan Borich. Adapun persamaan yang digunakan adalah sebagai berikut (Borich, 1994:385). Instrumen yang baik memiliki nilai $\mathrm{R} \geq 75 \%$.

Uji perbedaan kemampuan pemahaman konsep dan nilai karakter dilakukan dengan uji multivariat (MANOVA) dengan bantuan program SPSS 21.Uji prasyarat terdiri atas uji normalitas multivariat, uji homogenitas matriks varianskovarians, serta uji homogenitas varians.Kriteria pengujian adalah apabila nilai sig $>0,05$, maka data berdistribusi normal. Apabila nilai $s i g \leq 0,05$, maka data tidak berdistribusi normal.

Apabila diperoleh hasil bahwa pembelajaran menggunakan perangkat yang dikembangkan memberikan pengaruh yang signifikan terhadap peningkatan kemampuan pemahaman konsep dan nilai karakter, selanjutnya ditentukan pengaruhnya (effect size).Penentuan effect size dapat menggunakan persamaan berikut.

Effect size $=\frac{\text { Rerata kelas eksperimen }- \text { Rerata kelas kontrol }}{\text { Standar deviasi }}$

Interpretasi nilai effect size menggunakan interpretasi yang dipaparkan oleh Coe (2002:3).

Langkah selanjutnya adalah menentukan persentase keterlaksanaan RPP yang dihitung denga menggunakan persamaan sebagai berikut.

Persentase $=\frac{\Sigma(\text { butir terlaksana })}{\Sigma(\text { butir kegiatan })} \times 100 \%$

\section{HASIL DAN PEMBAHASAN \\ Hasil \\ Validasi Instrumen Penilaian}

Sebelum dilakukan penilaian oleh ahli, instrumen penilaian perangkat pembelajaran yang dikembangkan terlebih dahulu divalidasi dalam forum group discussion (FGD) serta divalidasi oleh seorang dosen ahli. Berdasarkan validasi instrumen, dapat disimpulkan bahwa instrumen penilaian perangkat pembelajaran $100 \%$ valid digunakan oleh expert judgment. Uji validitas menggunakan Aiken's V diperoleh nilai validitas seluruh butir penilaian $\geq 0.88$. Selain itu, dilakukan uji kesepakatan Borich.Uji tersebut menunjukkan bahwa koefisien reliabilitas instrumen memiliki nilai $\geq 75 \%$. Berdasarkan nilai tersebut, dapat disimpulkan bahwa instrumen termasuk dalam kategori reliabel.

\section{Penilaian Perangkat Pembelajaran}

Hasil penilaian perangkat pembelajaran oleh expert judgment disajikan Tabel 2.

\section{Tabel 2. Penilaian Perangkat Pembelajaran}

\begin{tabular}{llcl}
\hline No. & Perangkat & Rerata & Kategori \\
& Pembelajaran & & \\
\hline 1. & RPP & 4,75 & Sangat Baik \\
2. & LKS & 4,67 & Sangat Baik \\
3. & Handout & 4,7 & Sangat Baik \\
4. & Tes Kemampuan & 4,67 & Sangat Baik \\
& Pemahaman Konsep & & \\
5. & Angket dan Lembar & 4,75 & Sangat Baik \\
& Observasi Karakter & & \\
6. & Angket Respon Siswa & 4,62 & Sangat Baik \\
\hline
\end{tabular}

\section{Uji Empirik}

Uji empirik dilakukan menggunakan hasil post test kemampuan pemahaman konsep dan karakter siswa serta hasil respon siswa. Uji empirik dilakukan menggunakan bantuan program quest. Model IRT yang digunakan dalam analisis ini yaitu model 1-PL. Dari 30 butir soal tes kemampuan pemahaman konsep, 26 butir soal lolos. Selain uji validitas, uji reliabilitas juga dilakukan terhadap butir soal dan hasilnyadisajikan pada Tabel 3.

Tabel 3. Hasil Uji Reliabilitas Tes Kemampuan Pemahaman Konsep

\begin{tabular}{lcl}
\hline $\begin{array}{l}\text { Dasar } \\
\text { Reliabilitas }\end{array}$ & $\begin{array}{l}\text { Nilai } \\
\text { validitas }\end{array}$ & Kriteria \\
\hline Case Estimates & 0,7 & $\begin{array}{l}\text { Reliabel } \\
\text { Internal Consistency }\end{array}$ \\
& 0,82 & $\begin{array}{l}\text { Sangat } \\
\text { Reliabel }\end{array}$ \\
\hline
\end{tabular}

Uji empirik untuk angket karakter siswa menggunakan bantuan program quest. Angket karakter terdiri atas 16 butir.Berdasarkan uji empirik, seluruh butir angket karakter termasuk dalam kriteria baik. Hasil uji reliabilitas butir angket karakter disajikan pada Tabel 4.

Tabel 4. Hasil Uji Reliabilitas Butir Angket Karakter

\begin{tabular}{|c|c|c|}
\hline Dasar Reliabilitas & $\begin{array}{c}\text { Nilai } \\
\text { validitas }\end{array}$ & Kriteria \\
\hline Case Estimates & 0,91 & $\begin{array}{c}\text { Sangat } \\
\text { Reliabel }\end{array}$ \\
\hline Internal Consistency & 0,9 & $\begin{array}{c}\text { Sangat } \\
\text { Reliabel }\end{array}$ \\
\hline
\end{tabular}


Hasil uji empirik pada 35 butir angket respon siswa menunjukkan bahwa seluruh butir angket respon siswa termasuk dalam kriteria baik dan hasilnya ditunjukkan pada Tabel 5 .

Tabel 5. Hasil Uji Reliabilitas Butir Angket Respon Siswa

\begin{tabular}{lcc}
\hline Dasar Reliabilitas & $\begin{array}{c}\text { Nilai } \\
\text { validitas }\end{array}$ & Kriteria \\
\hline Case Estimates & 0,94 & $\begin{array}{c}\text { Sangat } \\
\text { Reliabel } \\
\text { Sangat } \\
\text { Reliabel }\end{array}$ \\
\hline
\end{tabular}

\section{Keterlaksanaan RPP}

Keterlaksanaan RPP pada ketiga pertemuan memiliki persentase diatas $75 \%$. Hal ini mengandung arti bahwa pembelajaran yang berlangsung sesuai dengan RPP yang dikembangkan.

\section{Peningkatan Kemampuan Pemahaman Kon- sep}

Data peningkatan kemampuan pemahaman konsep diperoleh berdasarkan hasil uji gain dan $N$-gain. Grafik rerata nilai pretest dan posttest kemampuan pemahaman konsep siswa disajikan pada Gambar 1.

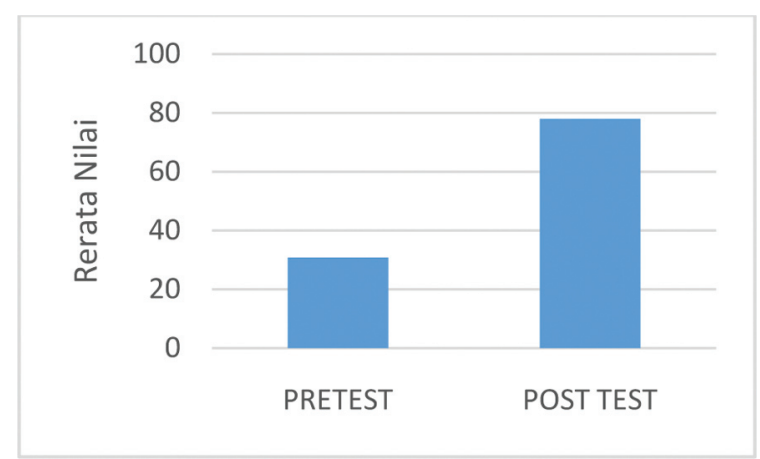

Gambar 1. Grafik Rerata Nilai Kemampuan Pemahaman Konsep pada Uji Coba Terbatas

Gambar 1 menunjukkan bahwa kemampuan pemahaman konsep siswa mengalami peningkatan dengan selisih pretes dan postessebesar 47,23. Berdasarkan hasil gain siswa, dapat ditentukan nilai $N$-Gain. Nilai $N$-Gain untuk kelas pada uji terbatas disajikan pada Tabel 6 .
Tabel 6. Nilai N-Gain Kemampuan Pemahaman Konsep Siswa pada Uji Coba Terbatas

\begin{tabular}{ccc}
\hline Kemampuan & $\boldsymbol{N}$-Gain & Kategori \\
\cline { 2 - 3 } Pemahaman Konsep & 0,68 & Sedang \\
\hline
\end{tabular}

\section{Peningkatan Persentase KKM}

Peningkatan persentase KKM ditentukan dengan membandingkan skor yang diperoleh setiap siswa dengan KKM mata pelajaran Fisika yang telah ditetapkan sekolah. KKM yang telah ditentukan SMA Negeri 5 Purworejo pada mata pelajaran fisika adalah 75 . Grafik persentase ketuntasan siswa untukpretes dan postes kemampuan pemahaman konsep siswa disajikan pada Gambar 2.

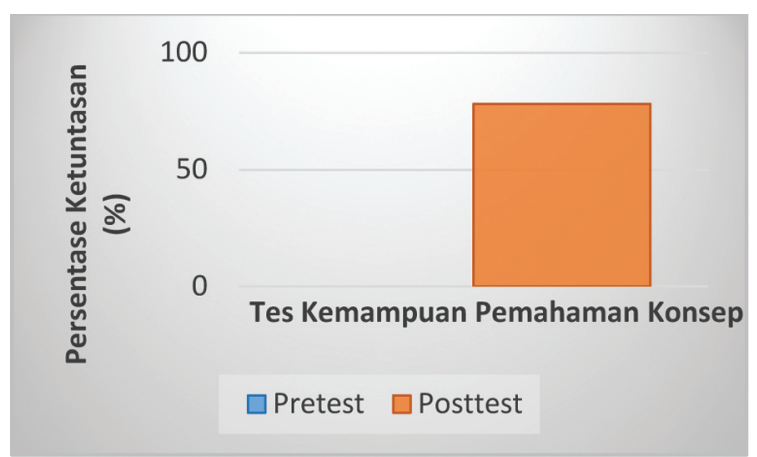

\section{Gambar 2. Grafik Persentase ketuntasan} pada Uji Coba Terbatas

Persentase ketuntasan siswa pada pretes adalah $0 \%$ sedangkan pada postes adalah $78,125 \%$ sehingga ketuntasan siswa mengalami peningkatan dengan selisih pretest dan posttest sebesar $78.125 \%$.

\section{Peningkatan Nilai Karakter Siswa}

Peningkatan nilai karakter siswa pada uji coba terbatas ditentukan menggunakan hasil angket dan observasi karakter yang diberikan kepada siswa sebelum (pre) dan setelah (post) diberikan rangkaian pembelajaran menggunakan perangkat yang telah dikembangkan. Sebelum dilakukan analisis, data diubah menjadi skala interval.

Peningkatan nilai karakter siswa juga diperoleh melalui uji gain dan $\mathrm{N}$-gain. Rerata nilai persentase pretest dan posttest karakter siswa disajikan pada Gambar 3. 


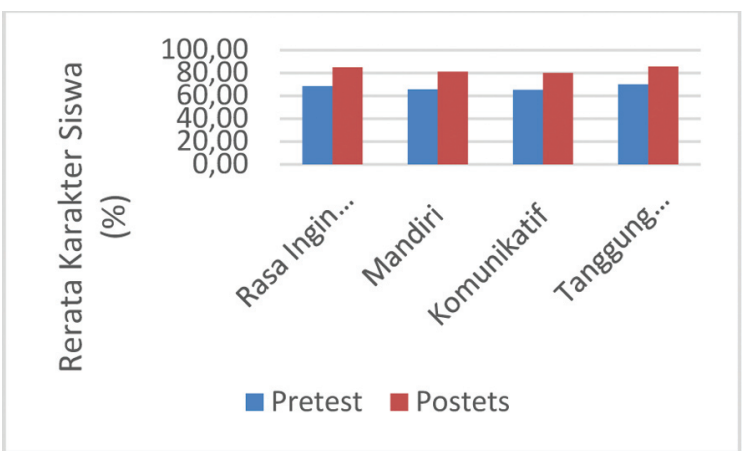

Gambar 3. Grafik Nilai Rerata Pretest dan Posttest Karakter Siswa pada Uji Coba Terbatas

Karakter rasa ingin tahu, mandiri, komunikatif, dan tanggung jawab mengalami peningkatan. Adapun selisih pretes dan postes untuk karakter rasa ingin tahu sebesar $16,11 \%$, karakter mandiri sebesar $15,72 \%$, karakter komunikatif sebesar $14,81 \%$, dan karakter tanggung jawab sebesar $15,62 \%$. Nilai $N$-Gain seluruh siswa pada uji coba terbatas disajikan pada Tabel 7.

\section{Angket Respon Siswa}

Respon siswa diberikan terhadap perangkat yang dikembangkan berupa handout dan LKS. Hasil respon siswa uji coba terbatas disajikan pada Tabel 8 dan Tabel 9.

Tabel 9. Rerata Skor Respon Siswa Terhadap Handout pada Uji Coba Terbatas

\begin{tabular}{ccc}
\hline Aspek & Rerata Skor & Kategori \\
\hline Materi & 4,05 & Sangat Baik \\
Kebahasaan & 3,81 & Baik \\
Tampilan & 3,93 & Baik \\
\hline
\end{tabular}

Tabel 10.Rerata Skor Respon Siswa Terhadap LKSpada Uji Coba Terbatas

\begin{tabular}{ccc}
\hline Aspek & Rerata Skor & Kategori \\
\hline Didaktik & 3,93 & Baik \\
Konstruksi & 4,37 & Sangat Baik \\
Teknis & 4,54 & Sangat Baik \\
\hline
\end{tabular}

\section{Keterlaksanaan RPP}

Keterlaksanaan RPP pada ketiga pertemuan memiliki persentase diatas $75 \%$. Hal ini mengandung arti bahwa pembelajaran yang berlangsung sesuai dengan RPP yang dikembangkan.

\section{Peningkatan Kemampuan Pemahaman Kon- sep}

Data peningkatan kemampuan pemahaman konsep diperoleh berdasarkan hasil uji gain dan $N$-gain. Grafik rerata nilai pretest dan posttest kemampuan pemahaman konsep siswa eksperimen dan kelas kontrol disajikan pada Gambar 4.

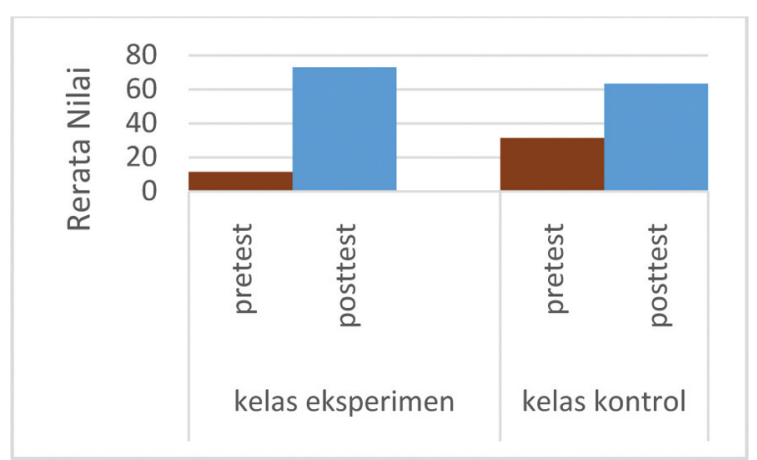

Gambar 4. Grafik Rerata Nilai Kemampuan Pemahaman Konsep Kelas Eksperimen dan Kontrol pada Uji Coba Lapangan

Tabel 7. Nilai N-Gain Karakter Uji Coba Terbatas

\begin{tabular}{ccccc}
\hline Karakter & $\begin{array}{c}\text { Rasa Ingin } \\
\text { Tahu }\end{array}$ & Mandiri & Komunikatif & $\begin{array}{c}\text { Tanggung } \\
\text { Jawab }\end{array}$ \\
\hline N-Gain & 0,51 & 0,46 & 0,43 & 0,43 \\
Kriteria & Sedang & Sedang & Sedang & Sedang \\
\hline
\end{tabular}

Tabel 10. Nilai $N$-Gain Kemampuan Pemahaman Konsep Siswa pada Uji Coba Lapangan

\begin{tabular}{clcc}
\hline $\begin{array}{c}\text { Kemampuan } \\
\text { Pemahaman } \\
\text { Konsep }\end{array}$ & Kelas & $N$-Gain & Kategori \\
\cline { 2 - 4 } & Kontrol & 0,74 & Tinggi \\
& & 0,46 & Sedang \\
\hline
\end{tabular}


Kemampuan pemahaman konsep siswa kelas ekperimen mengalami peningkatan dengan selisih pretest dan posttest sebesar $56,61 \%$ sedangkan kelas kontrol sebesar 31,97\%. Berdasarkan hasil gain siswa, maka dapat ditentukan nilai $\mathrm{N}$-Gain. Nilai $\mathrm{N}$-Gain untuk kelas pada uji coba lapangan disajikan pada Tabel 10 .

\section{Peningkatan Persentase KKM}

KKM yang telah ditentukan SMA Negeri 1 Purworejo pada mata pelajaran fisika adalah 75 . Grafik persentase ketuntasan siswa, baik pretest dan posttest kemampuan pemahaman konsep siswa pada kelas eksperimen dan kontrol disajikan pada Gambar 5.

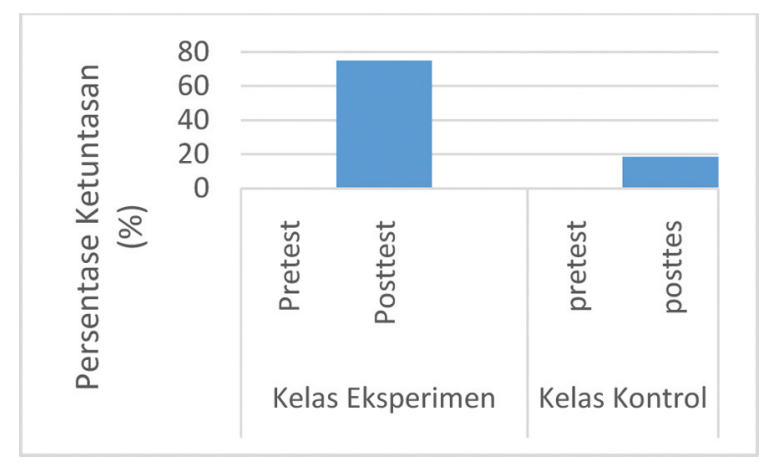

\section{Gambar 5. Grafik Persentase Ketuntasan Kelas Eksperimen dan Kontrol pada Uji Coba Lapangan}

Persentase ketuntasan siswa kelas eksperimen dan mengalami peningkatan. Persentase peningkatan ketuntasan pada kelas eksperimen sebesar $75 \%$ sedangkan pada kelas kontrol sebesar $18,75 \%$.

\section{Peningkatan Nilai Karakter Siswa}

Peningkatan nilai karakter siswa juga diperoleh melalui uji gain dan $\mathrm{N}$-gain. Rerata nilai persentase pretest dan posttest karakter siswa kelas eksperimen dan kontrol disajikan pada Gambar 6 dan 7.

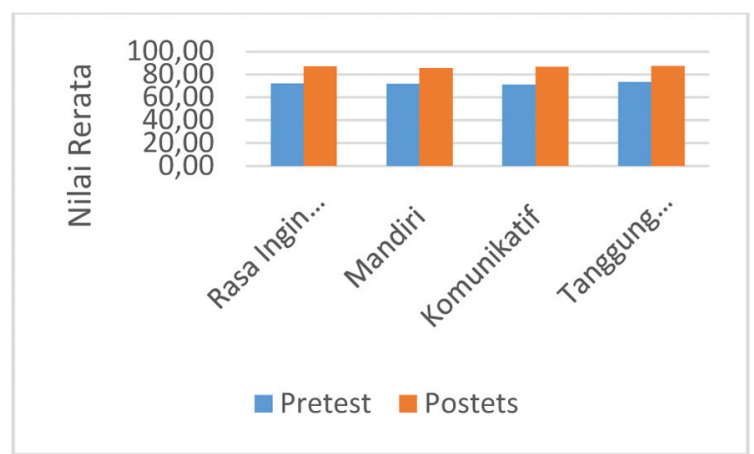

Gambar 6. Grafik Nilai Rerata Pretest dan Posttest Karakter Siswa Kelas Eksperimen pada Uji Coba Lapangan

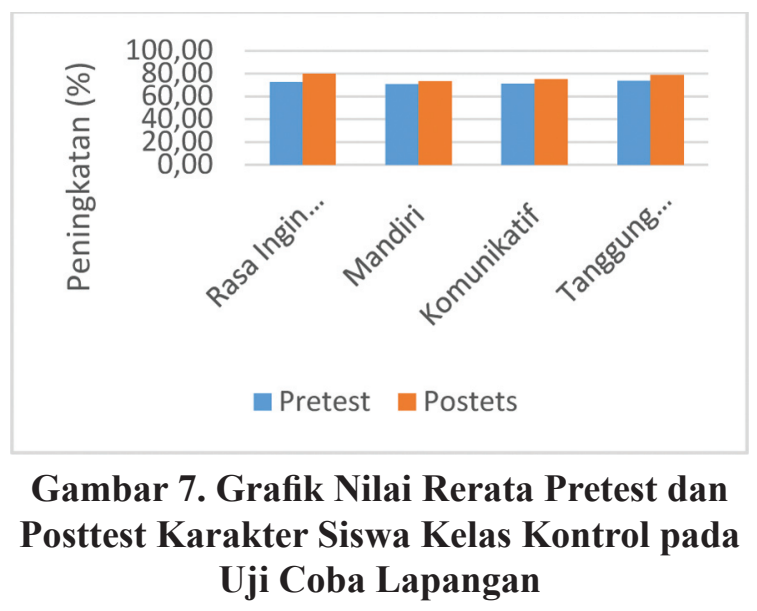

Karakter rasa ingin tahu, mandiri, komunikatif, dan tanggung jawab, baik kelas eksperimen maupun kelas kontrol mengalami peningkatan. Selisih pretes dan postes kelas eksperimen untuk karakter rasa ingin tahu sebesar 14,60\%, karakter mandiri sebesar $13,54 \%$, karakter komunikatif sebesar $15,61 \%$, dan karakter tanggung jawab sebesar $14,28 \%$. Selisih pretest dan posttest kelas kontrol untuk karakter rasa ingin tahu sebesar 7,41\%, karakter mandiri sebesar 2,66\%, karakter komunikatif sebesar 4,02\%, dan karakter tanggung jawab sebesar 5,01\%. Nilai N-Gain kelas eksperimen dan kelas kontrol pada uji coba lapangan disajikan pada Tabel 11.

Tabel 12. Hasil Manova Kemampuan Awal Siswa

\begin{tabular}{lccccc}
\hline Effect & Value & F & Hypothesis df & Error df & Sig. \\
\hline Pillai's Trace & 0,081 & 1,022 & 5 & 58 & 0,413 \\
Wilks' Lambda & 0,919 & 1,022 & 5 & 58 & 0,413 \\
Hotelling's Trace & 0,088 & 1,022 & 5 & 58 & 0,413 \\
Roy's Largest Root & 0,088 & 1,022 & 5 & 58 & 0,413 \\
\hline
\end{tabular}


Tabel 11.Nilai N-Gain Karakter Uji Coba Lapangan

\begin{tabular}{|c|c|c|c|}
\hline Kelas & Karakter & $N$-Gain & Kategori \\
\hline \multirow{4}{*}{ Eksperimen } & $\begin{array}{l}\text { Rasa Ingin } \\
\text { Tahu }\end{array}$ & 0,53 & Sedang \\
\hline & Mandiri & 0,48 & Sedang \\
\hline & Komunikatif & 0,54 & Sedang \\
\hline & $\begin{array}{l}\text { Tanggung } \\
\text { Jawab }\end{array}$ & 0,53 & Sedang \\
\hline \multirow{4}{*}{ Kontrol } & $\begin{array}{l}\text { Rasa Ingin } \\
\text { Tahu }\end{array}$ & 0,27 & Rendah \\
\hline & Mandiri & 0,09 & Rendah \\
\hline & Komunikatif & 014 & Rendah \\
\hline & $\begin{array}{l}\text { Tanggung } \\
\text { Jawab }\end{array}$ & 0,19 & Rendah \\
\hline
\end{tabular}

\section{Analisis Perbedaan Kemampuan Pemahaman Konsep dan Nilai Karakter}

Analisis perbedaan kemampuan pemahaman konsep dan nilai karakter terdiri atas dua tahapan, yaitu uji prasyarat analisis multivariat dan uji multivariat. Data yang adalah nilai pretes dan gain kemampuan pemahaman konsep dan nilai karakter siswa.

Berdasarkan uji normalitas multivariat, data kemampuan awal dan gain siswa berdistribusi normal. Berdasarkan uji kesamaan matriks varians-kovarians, data kemampuan awal (pretest) dan peningkatan kemampuan (gain) siswa baik pemahaman konsep maupun nilai karakter memiliki matriks varian-kovarians yang relatif sama. Berdasarkan uji kesamaan varians, data kemampuan siswa serta gain untuk kemampuan pemahaman konsep dan nilai karakter tidak memiliki perbedaan varians data atau varians data homogen. Berdasarkan uji prasyarat, seluru data memenuhi persyaratan untuk dilanjutkan pada manova.Hasil uji manova disajikan pada Tabel 12 dan 13.

Tabel 12 menunjukkan bahwa tidak ada perbedaan rata-rata kemampuan awal siswa pada kelas eksperimen dan kontrol.Tidak adanya perbedaan tersebut menandakan bahwa kemampuan awal siswa pada kelas eksperimen dan kelas kontrol setara. Tabel 13 memperloihatkan bahwa terdapat perbedaan rata-rata yang signifikan antara gain kemampuan pemahaman konsep dan nilai karakter siswa pada kelas eksperimen yang menggunakan perangkat pembelajaran fisika aktif berbasis local wisdom Kabupaten Purworejo dengan kelas kontrol yang menggunakan perangkat pengembangan guru.

Berdasarkan uji manova yang telah dilakukan, pembelajaran menggunakan perangkat yang dikembangkan menunjukkan pengaruh yang signifikan terhadap peningkatan pemahaman konsep dan nilai karakter siswa. Selanjutnya, ditentukan effect size untuk menntukan seberapa besar keefektifan dari penggunaan perangkat yang dikembangkan. Hasil perhitungan effect size ditunjukkan pada Tabel 14.

Tabel 14. Hasil Perhitungan Effect Size

\begin{tabular}{llcc}
\hline No. & $\quad$ Variabel & $\begin{array}{c}\text { Effect } \\
\text { Size }\end{array}$ & $\begin{array}{c}\text { Persentase } \\
\text { Keefektifan } \\
\text { Perangkat yang } \\
\text { Dikembangkan } \\
(\%)\end{array}$ \\
\hline & & Kemampuan \\
1. & $\begin{array}{l}\text { Pemahaman } \\
\text { Konsep }\end{array}$ & 1,2 & 88 \\
2. & Rasa Ingin Tahu & 0,8 & 79 \\
3. & Mandiri & 1,2 & 88 \\
4. & Komunikatif & 1,2 & 88 \\
5. & Tanggung Jawab & 0,9 & 82 \\
\hline
\end{tabular}

Perangkat pembelajaran fisika aktif tipe learning tournament berbasis local wisdom Kabupaten Purworejo efektif dalam meningkatkan kemampuan pemahaman konsep dan nilai karakter.

\section{Angket Respon Siswa}

Respon siswa berupa penilaian, komentar, serta saran perbaikan. Respon siswa diberikan pada perangkat pembelajaran berupa handout dan LKS diakhir rangkaian pembelajaran. Hasil respon siswa terhadap handout dan LKS ditampilkan pada Tabel 15.

Tabel 13. Hasil Manova Gain Kemampuan Pemahaman Konsep dan Nilai Karakter Siswa

\begin{tabular}{lccccc}
\hline \multicolumn{1}{c}{ Effect } & Value & F & $\begin{array}{c}\text { Hypothesis } \\
\text { df }\end{array}$ & Error df & Sig. \\
\hline Pillai's Trace & 0,801 & 46,629 & 5 & 58,000 & 0,000 \\
Wilks' Lambda & 0,199 & 46,629 & 5 & 58,000 & 0,000 \\
Hotelling's Trace & 4,020 & 46,629 & 5 & 58,000 & 0,000 \\
Roy's Largest Root & 4,020 & 46,629 & 5 & 58,000 & 0,000 \\
\hline
\end{tabular}


Tabel 15: Respon Siswa

\begin{tabular}{cclcc}
\hline No. & $\begin{array}{c}\text { Perangkat } \\
\text { Pembelajaran }\end{array}$ & \multicolumn{1}{c}{ Aspek } & $\begin{array}{c}\text { Rerata } \\
\text { Skor }\end{array}$ & Kategori \\
\hline & & Materi & 4,20 & $\begin{array}{c}\text { Sangat } \\
\text { Baik }\end{array}$ \\
1. & Handout & Kebahasaan & 4,23 & $\begin{array}{c}\text { Sangat } \\
\text { Baik }\end{array}$ \\
& & Tampilan & 3,93 & Baik \\
& & Didaktik & 4,34 & $\begin{array}{c}\text { Sangat } \\
\text { Baik }\end{array}$ \\
& & & 4,22 & $\begin{array}{c}\text { Sangat } \\
\text { 2, }\end{array}$ \\
& LKS & Konstruksi & & Sangat \\
& & & 4,22 & Baik \\
\hline
\end{tabular}

\section{Pembahasan}

Rencana Pelaksanaan Pembelajaran di dalam penelitian ini dikembangkan berdasarkan Permendikbud Nomor 65 Tahun 2013. Komponen dalam RPP antara lain: perumusan tujuan pembelajaran, pemilihan dan pengorganisasian materi ajar mencakup model, pendekatan, dan metode pembelajaran, pemilihan sumber/media pembelajaran, langkah/kegiatan pembelajaran, dan evaluasi hasil belajar. Langkah pembelajaran dirancang dengan mengacu pada pembelajaran aktif tipe learning tournament serta berbasis pada local wisdom dengan tema upacara adat Jolenan. Pembelajaran yang disusun hanya terfokus pada tujuan pengembangan pemahaman konsep dan nilai karakter siswa. Upacara adat Jolenan jika dicermati mengandung aspek fisika antara lain mekanika. Berdasarkan atas beberapa temuan penelitian, khususnya pada aspek kompetensi pemahaman konsep mekanika ternyata masih banyak dijumpai adanya miskonsepsi. Halim, et al. (2014) menyatakan bahwa sebagian besar siswa memiliki perspektif negatif terhadap fisika. Hal ini disebabkan mereka gagal mencapai nilai tes terbaiknya karena masih adanya miskonsepsi atau kurangnya pemahaman konsep-konsep fisika terutama konsep kesetimbangan gaya-gaya. Ditemukan juga bahwa penerapan strategi pembelajaran yang berbasis budaya berdampak pada peningkatan kemampuan siswa dalam membuat hubungan antara konsep-konsep sains dengan isuisu dalam dunia nyata sebesar 36,7\% (Grimberg \& Gummer, 2012).

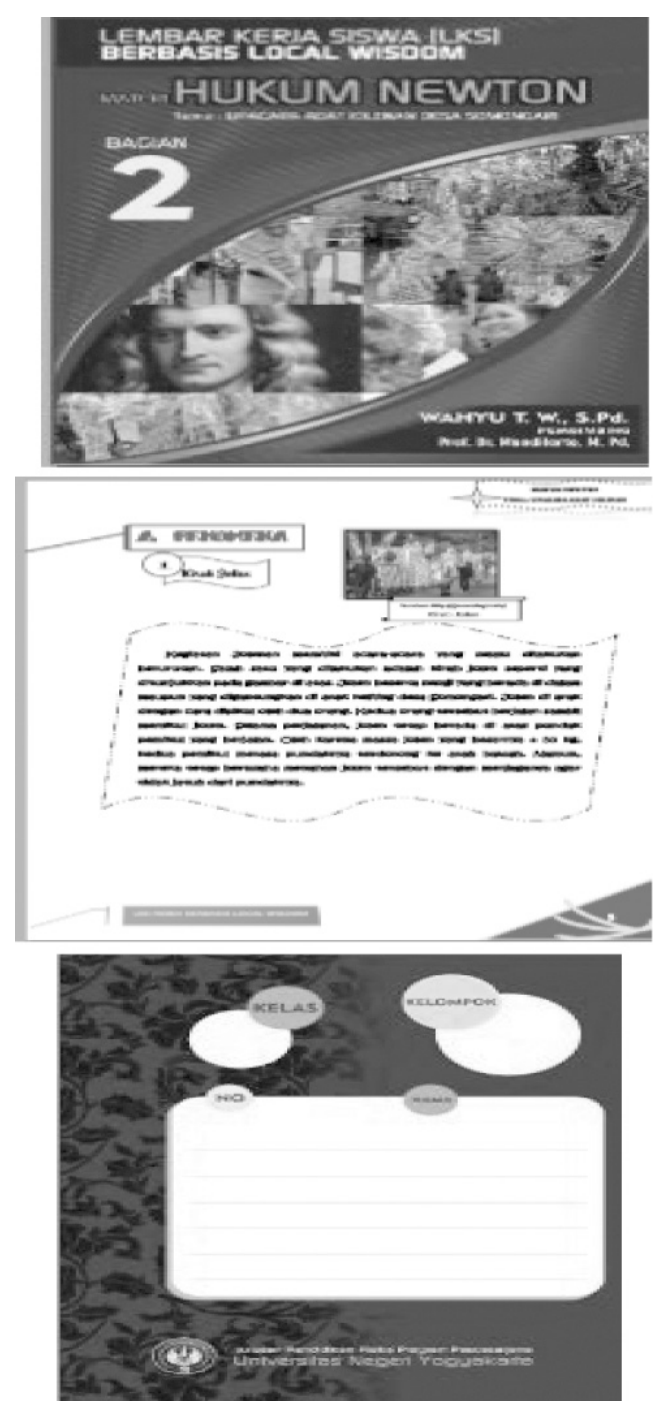

Gambar 8. Tampilan LKS yang Dikembangkan

Lembar kerja siswa dalam penelitian ini disusun berdasarkan prinsip belajar aktif terkait dengan konsep hukum-hukum Newton. Prinsip ini dirujuk berdasarkan temuan bahwa keyakinan siswa dapat diraih apabila siswa banyak dilibatkan di dalam kegiatan menemukan konsep secara aktif dalam proses pembelajaran (Sahin, 2010:534). LKS yang disusun sebanyak tiga buah untuk masing-masing pertemuan. Aktivitas yang disusun dalam LKS disesuaikan dengan sintaks pembelajaran fisika aktif tipe learning tournament. LKS tersusun atas panduan belajar, peta kompetensi, serta menyajikan fenomena dan kegiatan yang menunjang peningkatan pemahaman konsep dan karakter siswa.Selain itu, pada halaman paling belakang LKS dilengkapi dengan lembar catatan khusus. Lembar ini berfungsi sebagai tempat siswa untuk mencatat hal-hal penting dalam rangka pemahaman konsep fisika. Tampilan LKS ini disajikan pada Gambar 9. 

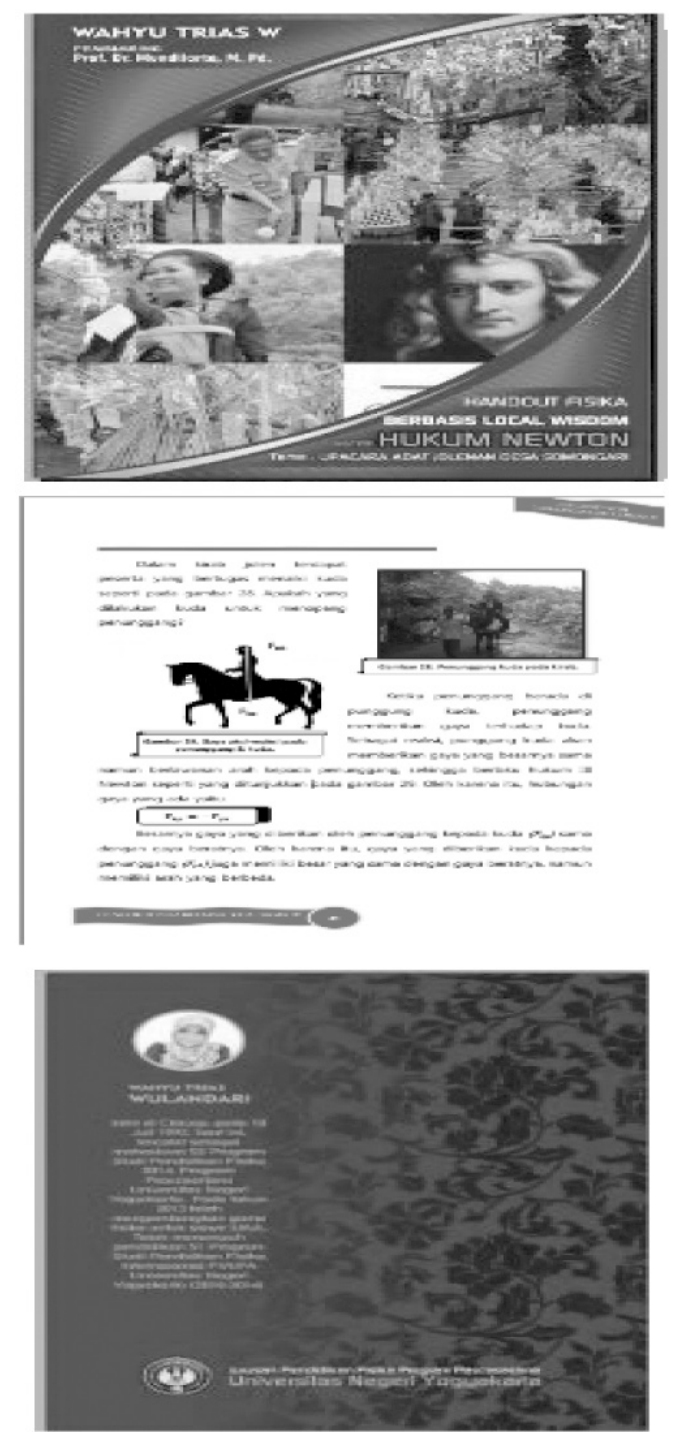

Gambar 9. Tampilan handout yang Dikembangkan

Berdasarkan hasil penilaian expert judgment, perangkat pembelajaran yang dikembangkan termasuk dalam kategori sangat baik serta layak digunakan dengan revisi berdasarkan saran dan komentar yang diberikan. Hasil uji empirik tes kemampuan pemahaman konsep fisika menunjukkan bahwa 26 butir soal lolos dan dapat digunakan dalam pengukuran kemampuan pemahaman konsep fisika, sedangkan 4 butir lainnya tidak lolos. Hasil uji empirik tes kemampuan pemahaman konsep fisika juga menunjukkan bahwa instrumen tes termasuk dalam kategori reliabel sehingga mampu menghasilkan pengukuran yang konsisten. Uji empirik untuk angket karakter siswa serta angket respon siswa menunjukkan bahwa seluruh butir lolos dan dapat digunakan dalam mengukur peningkatan nilai karakter siswa. Selain itu, butirbutir termasuk dalam kategori reliabel sehingga dapat memberikan hasil pengukuran yang konsisten. Dengan demikian, perangkat pembelajaran yang dihasilkan diyakini dapat diimplementasikan sesuai dengan tujuan pengembangan.

Berdasarkan atas nilai $N$-Gain yang diperoleh, kemampuan pemahaman konsep siswa meningkat dengan kategori "sedang" pada uji coba terbatas dan kategori "tinggi" pada uji implementasi di lapangan. Selain itu, persentase kenaikan ketuntasan siswa dapat meningkat dengan nilai yang cukup signifikan. Berdasarkan uji multivariat dan effect size, perangkat pembelajaran fisika yang telah dikembangkan terbukti mampu meningkatkan kemampuan pemahaman konsep fisika dan nilai karakter secara signifikan.Hasil tersebut selain sesuai dengan tujuan pengembangannya juga sesuai dengan temuan penelitian-penelitian sebelumnya (Antwi et al, 2011:90). Dari temuan sebuah pendekatan empirik pada pembelajaran sains yang diujicobakan di China dan Amerika Serikat ternyata dapat memberikan hasil belajar sains yang sangat bervariasi ditinjau dari beberapa variabel bebas seperti jenis kelamin, sikap, latar belakang keluarga, pengalaman belajar di kelas, dan upaya individual (Wang \& Staver, 1996). Hasil penelitian Widodo \& Kadarwati (2013) pada siswa-siswa SMA kelas XI program IPA menemukan bahwa pembelajaran IPA yang menerapkan prinsip higher order thinking berbasis pemecahan masalah memberikan skor hasil belajar dan skor aktivitas siswa meningkat jauh di atas batas ketuntasan minimal. Selain itu, nilai karakter dan respon siswa terhadap proses pembelajaran termasuk pada kategori baik.

Hal ini menunjukkan bahwa produk penelitian berupa perangkat pembelajaran fisika yang dikembangkan dengan berbasis pada local wisdom yang ada di Kabupaten Purworejo Jawa tengah, yaitu upacara adat Jolenan yang diintegrasikan dengan model physicsactive learning tournament secara menyakinkan mampu mendukung siswa SMA dalam meningkatkan kemampuan pemahaman konsep fisika dan nilai-nilai karakter. Adapun efek pengiring dari proses pengembangan produk ini adalah membantu program pemerintah Kabupaten Purworejo Jawa tengah dalam melestarikan serta menyebarluaskan informasi mengenai local wisdom yang ada.

\section{SIMPULAN}

Berdasarkan hasil pengembangan dan pembahasan, diperoleh kesimpulan sebagai berikut. 
(1) Penelitian pengembangan ini menghasilkan perangkat pembelajaran fisika aktif tipe learning tournament berbasis local wisdom Kabupaten Purworejo. Perangkat pembelajaran yang dikembangkan telah teruji secara teori maupun empiris layak digunakan dalam pembelajaran fisika. (2) Perangkat pembelajaran fisika aktif berbasis local wisdom yang dikembangkan dapat meningkatkan kemampuan pemahaman konsep. Hal ini ditunjukkan dengan nilai $\mathrm{N}$-Gain pada uji coba terbatas yang termasuk dalam kategori "sedang" dan uji coba lapangan yang termasuk dalam kategori “tinggi”. Selain itu ketuntasan siswa juga menunjukkan peningkatan yang signifikan. (3) Perangkat pembelajaran fisika aktif berbasis local wisdom yang dikembangkan dapat meningkatkan nilai karakter. Hal ini ditunjukkan dengan nilai N-gain pada uji coba terbatas dan uji coba lapangan yang termasuk dalam kategori "sedang". (4) Perangkat pembelajaran yang dikembangkan efektif meningkatkan kemampuan pemahaman konsep dan nilai karakter. Hal ini ditunjukkan dengan adanya perbedaan peningkatan kemampuan pemahaman konsep dan nilai karakter yang signifikan antara kelas eksperimen dan kelas kontrol, baik berdasarkan uji multivariat maupun effect size.

\section{UCAPAN TERIMA KASIH}

Diucapkan terima kasih kepada seluruh pihak yang telah membantu penelitian ini. Semoga hal tu menjadi bagian dari amal yang bernilai pahala.

\section{DAFTAR PUSTAKA}

Aiken, L.R. 1985. "Three Coefficients for Analyzing the Reliability and Validity of Ratings". Educational nd Psychological Measurement, 45, 131-142.

Antwi, V., Hanson, R., Sam, A., et al. 2011. "The Impact of Interactive-Engagement (IE) Teaching on Students Understanding of Concepts in Mechanics: The Use of Force Concept Inventory (FCI) and Mechanics Baseline Test (MBT)". International Journal of Educational Planning \& Administration, 1(1), 81-90. Online: http://www. ripublication.com/ijepa/ijepav1n1_9.pdf.

Ardan, A.S., Ardi, M., Hala, Y., et al. 2015. "Needs Assessment to Development of Biology Textbook for High School Class
X-Based the Local Wisdom of Timor". International Education Studies, 8 (4), 5259. Online:http://www.ccsenet.org/journal/ index.php/ies/article/view/46962.

Borich.(1994). Observation Skill for Effective Teaching. New York: Mcmillian Publishing.

Coe, Robert. (2002). It's the Effect Size, Stupid: What Effect Size is and Why It is Importan. British Educational Research Association annual conference, Exeter, 1-18.Diambil pada tanggal 18 Juli 2016, dari http://www. cem.org/attachments/ebe/ESguide.pdf.

Gray, T. 2010. Character Education in Schools.Essay, 7, artikel 21.Online: http://dc.cod.edu/cgi/viewcontent. cgi? article $=1116 \&$ context $=$ essai.

Grimberg, B. Irene \& Edith Gummer. 2012. Journal of Research in Science Teaching: 30 November 2012 DOI: 10.1002/tea.21066.

Hake, R. 1993.Analyzing Change/Gain Scores. Diambil pada tanggal 3 Februari 2014, dari http://www.physics.indiana.edu/ sdi/ AnalyzingChange-Gain.pdf.

Halim, L., Yong, T. K., \& Meerah,T. S. M. 2014. Overcoming Students' Misconceptions on Forces Equilibrium: An Action Research Study.Creative Education, 5,1032-1042. http://dx.doi.org/10.4236/ce.2014.511117

Morales, A.F., \& Toledano, M.C.M. 2013. Developing Creativity and Innovation through Collaborative Projects.Proceedings of the 2012 Conference on Creativity in Higher Education, Finland, 2(3), 70-82. Online:http://lbdconference.laurea.fi/pdf/ proceedings_2013.pdf.

Ninck, A. 2013. "Teaching and Learning for Innovation". Proceedings of the 2012 Conference on Creativity in Higher Education, Finland, 2(3), 9-19. Diambil pada tanggal 5 Juli 2015 dari http://lbdconference.laurea. fi/pdf/proceedings_2013.pdf. 
Pala, A. 2011. "The Need for Character Education". International Journal of Social Sciences And Humanity Studies, 3 (2), 23-32. Online:http://www.sobiad.org/ejournals/ journal_ijss/arhieves/2011_2/aynur_pala. pdf.

Sahin, M. 2010. "The Impact of Problem-Based Learning on Engineering Students' Beliefs about Physics and Conceptual Understanding of Energy and Momentum". European Journal of Engineering Education, 35 (5), 519-537. Online:http://www.tandfonline. com/doi/abs/10.1080/03043797.2010.487 149\#.VbTUX_ntmko.

Silay, N. 2014. Another type of Character Education: Citizenship Education. International Journal of Education. 6 (2), 1-10. Online: http://www.macrothink.org/journal/index. $\mathrm{php} / \mathrm{ije} /$ article/view/4949.

Sukardjo. 2006. Kumpulan Materi Evaluasi Pembelajaran. Yogyakarta: Program Pasca Sarjana UNY.

Thiagarajan, S., Semmel, D. S., \& Semmel, M. I. 1974. Instructional Development for Training Theacher of exceptional Children. Minnesota: Indiana University.
Wang, Jianjun \& John R. Staver.1996.An empirical approach toward the prediction of students' science achievement in the United States and Hubei, China.Journal of Research in Science Teaching. Online: DOI:10.1002/(SICI)10982736(199603) 33:3<283::AID-TEA3>3.0.CO;2-P.

Weno, I.H. 2010. "Pengembangan Model Modul IPA Berbasis Problem Solving Method Berdasarkan Karakteristik Siswa dalam Pembelajaran di SMP/MTs". Cakrawala Pendidikan 2, 1-13 diambil dari http:// journal.uny.ac.id/index.php/cp/article/ view/338.

Widodo, J. 2012. Urban Environment and Human Behaviour: Learning from History and Local Wisdom. Procedia - Social and Behavioral Sciences, 42, 6-11, diambil pada tanggal 1 Juli 2015 dari http://www.sciencedirect.com/science/ article/pii/S1877042812010439.

Widodo, Tri \& Sri Kadarwati. 2013. "Higher Order Thinking Berbasis Pemecahan Masalah untuk Meningkatkan Hasil Belajar Berorientasi Pembentukan Karakter Siswa". Cakrawala Pendidikan. Th. XXXII, No. 1, Februari 2013. 